\title{
UJI IDENTIFIKASI SENYAWA ALKALOID EKSTRAK METANOL DAUN KELOR (Moringa oleifera Lamk) MENGGUNAKAN METODE KROMATOGRAFI LAPIS TIPIS
}

\author{
Zulfiah $^{1}$, Herman ${ }^{2}$, Megawati ${ }^{3}$, Muhammad Farid Hasyim ${ }^{4}$, Murniati ${ }^{5}$, Sulfiyana H. Ambo Lau ${ }^{6}$, \\ Alfreds Roosevelt ${ }^{7}$, Yuniharce Kadang ${ }^{8}$, Nurul Izza ${ }^{9}$, Gerfan Patandung ${ }^{10}$ \\ Jurusan Farmasi Politeknik Sandi Karsa ${ }^{1,2,3,4,5,6,7,8,9,10}$
}

\begin{abstract}
ABSTRAK
Penelitian ini adalah hasil observasi laboratorium. Tujuan penelitian ini adalah untuk mengidentifikasi senyawa alkaloid yang terdapat pada daun kelor (Moringa oleifera L.). Identifikasi alkaloid dilakukan dengan metode maserasi dan dilanjutkan dengan metode Kromatografi Lapis Tipis (KLT). Hasil penelitian menunjukan daun kelor positif mengandung senyawa alkaloid. Harga Rf yang didapat 0,8
\end{abstract}

Kata kunci: Alkaloid, Daun Kelor, Maserasi, dan KLT (Kromatografi Lapis Tipis) 


\section{PENDAHULUAN}

\section{A. Latar Belakang}

Obat tradisional sudah dikenal dan digunakan di seluruh dunia sejak beribu tahun yang lalu. Obat tradisional dan tanaman obat banyak digunakan masyarakat menengah ke bawah terutama dalam upaya preventif, promotif, dan rehabilitatif. Penggunaan obat tradisional sebagai jamu telah meluas sejak zaman nenek moyang dan hingga kini terus dilestarikan sebagai warisan budaya (Duryatmo, 2015).

Bahan baku obat alami ini dapat berasal dari sumber daya alam biotik maupun abiotik. Sumber daya biotik meliputi jasad renik, flora, dan fauna serta biota laut sedangkan sumber daya abiotik meliputi sumber daya daratan, perairan, dan angkasa serta mencakup potensi yang ada di dalamnya.

Indonesia memiliki kekayaan alam yang cukup melimpah. Beraneka ragam tanaman obat tumbuh subur di alam Indonesia. Kekayaan alam ini bermanfaat besar bagi kesehatan penduduknya, bahkan bagi penduduk dunia. Beberapa penelitian membuktikan kepada dunia bahwa Indonesia sangat berpotensi sebagai tempat tumbuh dan berkembangnya bahan obat untuk masyarakat dunia (Fahey, 2016).

Kemampuan masyarakat terbatas untuk memperoleh obat-obat modern, sehingga menjadikan obat tradisional mempunyai makna yang sangat penting bagi masyarkat karena lebih mudah diperoleh tanpa menggunakan resep dokter (Pudjarwoto, dkk., 2013).

Sementara ini banyak orang beranggapan bahwa penggunaan tanaman obat atau obat tradisional relatif lebih aman dibandingkan obat sintetis. Walaupun demikian bukan berarti tanaman obat atau obat tradisional tidak memiliki efek samping yang merugikan bila penggunaanya kurang tepat.

Salah satu tumbuhan yang dapat dimanfaatkan baik sebagai bahan makanan maupun obat-obatan ialah tanaman kelor (Moringa oleifera L.). Kelor termasuk ke dalam familia Moringaceae dan memiliki banyak sebutan, seperti kelor, kerol, marangghi, moltong, kelo, keloro, kawano, dan ongge. Tanaman kelor tumbuh di dataran rendah maupun dataran tinggi. Tanaman ini memiliki ketinggian batang 7-11 meter.

Kelor diketahui mengandung lebih dari 90 jenis nutrisi berupa vitamin esensial, mineral, asam amino, antipenuaan dan antiinflamasi. Kelor mangandung 539 senyawa yang dikenal dalam pengobatan tradisional Afrika dan India serta telah digunakan dalam pengobatan tradisional untuk mencegah lebih dari 300 penyakit. Berbagai bagian dari tanaman kelor bertindak sebagai stimulan jantung dan peredaran darah, memiliki antitumor, antipiretik, antiepilepsi, antiinflamasi, antiulser, diuretik, antihipertensi, menurunkan kolesterol, antioksidan, antidiabetik, antibakteri dan antijamur (Toripah, dkk., 2014).

Seluruh bagian dari tanaman kelor telah dimanfaatkan sebagai bahan pangan maupun obat-obatan. Bagian tanaman ini yang sering digunakan sebagai obat adalah biji, daun, dan kulit kayu, dan berkhasiat sebagai anti diabetes dan antioksidan (Jaiswal, dkk., 2013; Pari, dkk., 2014). Jus dari akar tanaman kelor dapat digunakan untuk pengobatan iritasi eksternal. Suspensi dari biji kering diketahui sebagai koagulan. Beberapa manfaat lain dari tanaman kelor (Moringa oleifera L.) diantaranya kulit dari pohon kelor sebagai obat radang usus besar, daun kelor sebagai anti anemia, daun dan batang kelor dapat digunakan sebagai penurun tekanan darah tinggi dan obat diabetes (Giridhari, dkk., 2015).

Agar penggunaannya optimal, perlu diketahui informasi yang memadai tentang golongan senyawa kimia yang terkandung dalam tanaman obat tersebut. Bagian dari tumbuhan ini yang sering digunakan sebagai obat yaitu biji dan daunnya. Namun, untuk mengetahui kandungan senyawa kimia tanaman kelor yang tumbuh di Kab. ENDE Provinsi Nusa Tenggara Timur dan mengingat kondisi geografis masing-masing daerah berbeda kemungkinan ada perbedaan dalam kandungan senyawa kimia yang terdapat pada tanaman kelor.

\section{B. Rumusan Masalah}

Berdasarkan latar belakang diatas maka, rumusan masalah dalam penelitian ini adalah apakah daun Kelor (Moringa oleifera L.) mengandung senyawa alkaloid?

\section{Tujuan Penelitian}

Penelitian ini bertujuan untuk mengidentifikasi senyawa alkaloid ekstrak etanol daun Kelor (Moringa oleifera L.) dengan menggunakan pereaksi dan Kromatografi Lapis Tipis.

\section{Manfaat Penelitian}

Manfaat dari penelitian untuk memberikan informasi kepada masyarakat dan mahasiswa Farmasi mengenai kandungan Daun Kelor (Moringa oleifera L.) 


\section{METODE PENLITIAN}

\section{A. Jenis Penelitian}

Jenis penelitian ini yaitu penelitian observasi laboratorium untuk menunjukkan identifikasi senyawa alkaloid pada Daun Kelor (Moringa oleifera L.).

\section{B. Tempat dan Waktu Penelitian}

Penelitian ini akan dilakukan pada bulan Oktober 2020 di Laboratorium Farmakognosi \& Fitokimia Akademi Farmasi Sandi Karsa Makassar.

\section{Alat dan bahan}

Alat-alat yang di gunakan yaitu Seperangkat alat Maserasi, Batang pengaduk, Botol Semprot, Chember dan penutup Chember, Corong gelas, Cawan porselin, Erlenmeyer, Gelas ukur (pirex), Gelas kimia (pirex), Pipit tetes, Rak tabung, Sendok tanduk, Tabung reaksi (pirex).

Bahan-bahan yang digunakan Aquades $\left(\mathrm{H}_{2} \mathrm{O}\right)$, Aluminium Foil, Asam klorida $2 \mathrm{~N}$ (HCL), Etil Asetat, Kertas Saring, Lempeng $\mathrm{KLT}$, Metanol $\left(\mathrm{CH}_{4} \mathrm{O}\right)$, n-heksan, Pereaksi Mayer, Pereaksi Dragendrof, Pereaksi bounchardat, dan Sampel Ekstraksi Daun Kelor

\section{Metode Penelitian}

\section{a. Pengambilan Sampel}

Sampel daun Kelor (Moringa oleifera L.) yang diambil pada pagi. Daun yang diambil adalah daun segar dengan cara di petik satupersatu dari batang daunnya.

b. Pengelolaan Sampel

Daun kelor (Moringa oleifera L.) yang telah dikumpulkan, dibersihkan dengan cara dicuci di air yang mengalir lalu dipotongpotong kecil kemudian dikeringkan dengan cara diangin-anginkan, setelah kering sebagian diserbukkan lalu dilakukan proses ekstraksi kemudian dilakukan uji identifikasi kimia.

c. Pembuatan Ekstraksi

Sampel Daun Kelor (Moringa oleifera L.) yang telah dipotong-potong kecil, ditimbang 500 gram. Lalu dimasukkan ke dalam bejana maserasi dan ditambahkan metanol hingga terendam sempurna. Bejana ditutup rapat lalu didiamkan selama 3 x 5 hari dan sesekali diaduk selama 24 jam. Ekstrak yang diperoleh dikumpulkan kemudian diuapkan dengan menggunakan rotavapor untuk mendapatkan ekstrak kental dan senyawa di identifikasi secara kromatografi lapis tipis.

d. Pembuatan pereaksi

1. Pereaksi mayer
Sebanyak 5 gram kalium iodida dilarutkan dalam $10 \mathrm{ml}$ air suling. Kemudian ditambahakan larutan 1,36 gram $\mathrm{HgCl}$ dalam $60 \mathrm{ml}$ air suling. Larutan dikocok dan ditambahkan air suling hingga $100 \mathrm{ml}$.

2. Pereaksi dragendorf

Sebanyak 8 gram bismuth nitrat dilarutkan dalam asam nitrat $20 \mathrm{ml}$ kemudian dicampur dengan larutan kalium iodida sebanyak 27,2 gram dalam $50 \mathrm{ml}$ air suling. Campuran didiamkan sampai memisah sempurna. Larutan jernih diambil dan diencerkan dengan air secukupnya hingga $100 \mathrm{ml}$.

3. Pereaksi bouchardat

Sebanyak 4 gram kalium iodida ditimbang, dilarutkan dalam air suling secukupnya, lalu ditambahkan 2 gram iodium kemudian ditambahkan air suling hingga diperoleh larutan $100 \mathrm{ml}$.

e. Identifikasi secara kualitatif

1. Uji alkaloid

Ditimbang serbuk daun kelor (Moringa oleifera L.) sebanyak $10 \mathrm{mg}$, lalu ditambahkan sebanyak $1 \mathrm{ml}$ asam klorida $2 \mathrm{~N}$ dan $9 \mathrm{ml}$ air lalu dipanaskan diatas penangas air selama 2 menit didinginkan lalu disaring.

Filtrat dipakai untuk percobaan berikut:

a. Diambil 3 tetes filtrat, lalu ditambahkan 2 tetes pereaksi mayer menghasilkan endapan putih atau putih kekuningan.

b. Diambil 3 tetes filtrat, lalu ditambahkan 2 tetes pereaksi dragendorff menghasilkan endapan merah jingga.

c. Diambil 3 tetes filtrat, lalu ditambahkan 2 tetes peraksi bouchardat menghasilkan endapan coklat sampai kehitaman.

2. Uji Kromatografi Lapis Tipis (KLT)

Sebelum melakukan proses pemisahan secara KLT, lempeng KLT terlebih dahulu dipanaskan dalam oven dengan suhu $110^{\circ} \mathrm{C}$ selama 30 menit. Ekstrak metanol daun kelor disuspensikan dengan pelarut metanol. Setelah itu ditotolkan pada lempeng KLT yang sudah diberi garis batas elusi.

Identifikasi dengan metode kromatografi lapis tapis, menggunakan eluen etil asetat: $n$-heksan (7: 3). Setelah itu eluen dijenuhkan dalam chember dengan menggunakan kertas saring. Selanjutnya lempeng KLT yang telah 
ditotol dengan ekstrak dimasukkan kedalam chember dan kemudian dielusi.

Pengamatan terhadap penampakan noda dilakukan dengan menggunakan sinar UV $254 \mathrm{~nm}$ kemudian deteksi bercak dengan menyemprotkan pereaksi dragendorff, lalu dihitung harga Rf.

\section{HASIL DAN PEMBAHASAN}

\section{A. Hasil Penelitian}

Tabel I. Hasil pemeriksaan identifikasi senyawa alkaloid ekstrak metanol Daun Kelor (moringa oleifera lamk)

\begin{tabular}{|c|c|c|c|c|}
\hline \multirow{2}{*}{$\begin{array}{c}\text { Pemeriksaan } \\
\text { senyawa }\end{array}$} & \multirow{2}{*}{$\begin{array}{c}\text { Pereaksi } \\
\text { pelarut }\end{array}$} & \multicolumn{2}{|c|}{ Hasil pengamatan } & \multirow{2}{*}{ Ket } \\
\hline & & Pustaka & Pengamatan & \\
\hline \multirow[t]{3}{*}{ Alkaloid } & Mayer & $\begin{array}{c}\text { Endapan } \\
\text { putih atau } \\
\text { putih } \\
\text { kekuningan }\end{array}$ & $\begin{array}{l}\text { Tidak ada } \\
\text { endapan }\end{array}$ & Negatif \\
\hline & Dragendorff & $\begin{array}{c}\text { Endapan } \\
\text { merah } \\
\text { jingga }\end{array}$ & $\begin{array}{l}\text { Tidak ada } \\
\text { endapan }\end{array}$ & Negatif \\
\hline & Bouchardat & $\begin{array}{c}\text { Endapan } \\
\text { coklat. }\end{array}$ & $\begin{array}{c}\text { Endapan } \\
\text { colkat }\end{array}$ & Positif \\
\hline
\end{tabular}

Perhitungan Nilai Rf

$\mathrm{Rf}=$ Jarak noda yang ditempuh zat terlarut

Jarak yang ditempuh noda

Rf Merah jingga : $\frac{4}{5}=0,8$

Rf Merah muda : $\frac{1}{5}=0,2$

\section{B. Pembahasan}

Kelor (Moringa oleifera L.) adalah sejenis tumbuhan dari suku Moringacea. Tumbuhan ini dikenal sebagai tanaman ajaib yang biasa dipakai sebagai obat herbal untuk semua penyakit. Salah satu upaya dalam pencarian tumbuhan berkhasiat obat tesebut dapat dilakukan dengan uji kualitatif. Uji kualitatif adalah mengidentifikasi zat-zat kimia, mengenai unsur-unsur atau senyawa yang terdapat dalam suatu sampel. Identifkasi kandungan senyawa kimia yaitu pemeriksaan berdasarkan reaksi kimia antara kandungan tumbuhan dengan menggunakan pereaksi. Pada penelitian ini dilakukan pengujian yaitu uji alkaloid.

Pada pengujian senyawa alkaloid menggunakan tiga pereaksi yaitu pereaksi mayer, pereaksi dragendorff, dan pereaksi bouchardat. Pada pereaksi mayer tidak menghasilkan endapan putih kekuningan, sedangkan pada pereaksi dragendorff tidak menghasilkan endapan merah jingga, dan pada pereaksi bouchardat menghasil endapan coklat.
Sebelum melakukan proses identifkasi secara KLT, lempeng KLT terlebih dahulu diaktifkan dalam oven dengan suhu $110^{\circ} \mathrm{C}$ selama 10 menit. Setelah itu diberi garis batas atas dan batas bawah kemudian ekstrak daun kelor yang sudah disuspensikan ditotolkan pada lempeng KLT dan dielusi dengan eluen yang sesuai kemudian diamati dibawah lampu UV dengan gelombang $254 \mathrm{~nm}$ setelah itu disemprotkan dengan pereaksi dragendorff.

Proses identifikasi menggunakan kromatografi lapis tipis menggunakan eluen nheksan: etil asetat dengan perbandingan $7: 3$ tujuan dipilihnya dua pelarut tersebut karena masing-masing pelarut memiliki kepolaran yang berbeda sehingga senyawa-senyawa dengan kepolaran yang berbeda dapat terpisahkan dengan eluen tersebut. Deteksi bercak dengan menggunakan sinar UV $254 \mathrm{~nm}$. Pada UV 254 $\mathrm{nm}$ lempeng akan berfluoresensi sedangkan sampel akan tampak berwarna gelap.

Hasil setelah dilihat dibawah sinar UV 254 nm noda atau bercak tdiak tampak, dikarenakan tidak semua noda atau bercak yang menandakan adanya alkaloid bisa dilihat dengan UV $254 \mathrm{~nm}$ oleh karena itu lempeng KLT disemprot dengan pereaksi Dragendorff untuk menampakan noda atau bercaknnya. Setelah lempeng disemprot dengan pereaksi dragendorff terdapat bercak berwarna merah jingga yang dapat dilihat secara langsung. Bercak berwarna merah jingga ini menandakan adanya senyawa golongan alkaloid pada daun kelor. Harga Rf yang diperoleh setelah dihitung adalah 0,8 .

Berdasarkan Harborne (1987) nilai Rf 0,8 masuk dalam kisaran 12 alkaloid yang paling umum yaitu 0,07- 0,62 dengan melihat hasil identifikasi dengan pereaksi kimia dan kromatografi lapis tipis dapat dinyatakan bahwa daun kelor tersebut mengandung alkaloid.

\section{PENUTUP}

\section{A. Kesimpulan}

Hasil pengamatan pada lempeng KLT ekstrak metanol dengan menggunakan eluen nheksan: etil asetat dengan perbandingan $7: 3$ terdapat dua noda. Salah satu dari noda tersebut membentuk warna merah jingga, sehingga menandakan bahwa daun kelor mengandung senyawa alkaloid.

\section{B. Saran}

Disarankan untuk penelitian selanjutnya terhadap kandungan kimia lain pada tanamam ini, serta uji efek farmakologi. 


\section{DAFTAR PUSTAKA}

Azzahra Fathimah, dkk. 2015. Isolasi dan Karakterisasi Alkaloid dari Daun Sirih Merah (Piper crocatum Ruiz \& Pav). Prodi Farmasi, Fakultas MIPA, Unisba

Anas Yance, dkk. 2014. Ekstrak Daun Kelor (Moringa oleifera Lam.) Sebagai Peluruh Kalsium Batu Ginjal Secara In Vitro. Departemen Farmakologi dan Farmasi Klinik, Fakultas Farmasi Universitas Wahid Hasyim

Arora, S.D., Onsare, G.J., dan Kaur H., 2013, Bioprospecting moringa (Moringaceae): pengamatan mikrobiologi, Jurnal Farmakognosi dan Fitokimia;

Astuti Rosiana Widi. 2017. Isolasi Dan Identifikasi Senyawa Alkaloid Dalam Daun Kepel. Fakultas Matematika Dan Ilmu Pengetahuan Alam Universitas Negeri Semarang

Departemen Kesehatan Ri. 2000. Parameter Standar Umum Ekstrak Tumbuhan Obat. Jakarta: Direktorat Jenderal Pengawasan Obat Dan Makanan

Departemen Kesehatan Republik Indonesia. 1979. Farmakope Indonesia Edisi III. Jakarta: Direktorat Jenderal Pengawasan Obat Dan Makanan

Duke, J.A., 2001. Moringa oleifera Lam. (Moringaceae). Di: Duke, J.A. (Ed.), Handbook of Nuts. CRC Press, Boca Raton, FL, USA, hlm. 214-217

Duryatmo S. 2015. Dulu Hiasan Kini Obat. Trubus, 427:37.

Dwi arif sulistiono.2015. Tanin. Fakultas MIPA Universitas Mataram

Fahey JW. 2016. Moringa oleifera. Ulasan Tentang Bukti Medis Untuk Nurisi. Terapi Dan Profilaksis. Bagian 1. Trees for Life Journal, $1: 5$

Giridhari VVA, Malathi D, Geetha K. 2015. Tablet Anti Diabetes Daun Kelor. Jurnla Internasional Kesehatan Dan Gizi 2(1):1-5.

Hanani Endang. 2016. Analisis Fitokimia. Buku Kedokteran EGC: Jakarta

Jaiswal D, Rai PK, Kumar A, Mehta S, Watal G. 2013. Efek Daun Kelor. Leaves Ekstrak
Daun Mempunyai Efek Terhadap Tikus. Jurnal Ethnopharmacol, 123:392-296.

Mendieta-Araica B, Spörndly E, Reyes-Sánchez N, Salmerón-MirandaF, Halling M (2013).

Produksi Biomassa Dan Komposisi Kimia Moringa Oleifera Di Bawah Kepadatan Penanaman Yang Berbeda Dan Tingkat Pemupukan Nitrogen. Syst. 87: 81-92.17

Nurcahyati Erna. 2014. Khasiat Dahsyat Daun Kelor. Jakarata: Jendela Sehat

Pari L, Karamac M, Kosinska A, Rybarczyk A, Amarowicz R. 2014. Aktivitas Antioksidan Ektrak Daun Kelor. Jurnal Ilmu Makanan Dan Nutrisi. 57(2): 201-208.

Pudjarwoto T, Simanjuntak CH, Nur Indah P. 2013 Daya Antimikroba Obat Tradisional Diare Terhadap Beberapa Jenis Bakteri Enteropatogen. Cermin Dunia Kedokteran 76(1): 45-47.

Putra Pratama, dkk. 2016. Identifikasi Senyawa Kimia Ekstrak Etanol Daun Kelor (Moringa oleifera L). Bali: Fakultas Kedokteran Hewan, Universitas Udayana

Syamsu Hidayat. 1991. Inventarisasi Tanaman Obat Indonesia, Edisi II, Departemen Kesehatan RI, Jakarta

Toripah SS, Abidjulu J, Wehantouw F. 2014. Aktivitas Antioksidan Dan Kandungan Total Fenolik Ekstrak Daun Kelor (Moringa oleifera Lam). Pharmacon 3(4): 37-43.

Vanajakshi, V., Vijayendra, S.V.N., Varadaraj, M.C., Venkateswaran, G., Renu Agrawal. (2015). Optimalisasi Minuman Probiotik Berdasarkan Daun Kelor Dan Bit. LWT Ilmu dan Teknologi Pangan, 63: 1268-1273 